\title{
Lower Insulin Secretory Response to Glucose Induced by Artificial Nutrition in Children: Prolonged and Total Parenteral Nutrition
}

\author{
JACQUES BELTRAND, VIRGINIE COLOMB, EVELYNE MARINIER, CHRISTELLE DAUBROSSE, MARIANNE ALISON, \\ RÉMI BURCELIN, PATRICE D. CANI, DIDIER CHEVENNE, AND CLAIRE LÉVY MARCHAL
}

INSERM, U690 [J.B., L.M.], Paris, 75019, France, Université Paris 7, Paris, 75005 France; Department of Pediatric Gastroenterology and Nutrition [V.C.], Hôpital Necker-Enfants Malades, Paris, 75015, France; Department of Pediatric Gastroenterology and Nutrition [E.M.], Clinical Investigation Center [C.D.], Department of Pediatric Radiology [M.A.], Department of Biochemistry [D.C.], Hôpital Robert Debré, Paris, 75019, France; CNRS-UMR 5018 [R.B., P.D.C.], Université Paul Sabatier, Hôpital Toulouse Rangueil, Toulouse, 31403, France

\begin{abstract}
Long-term parenteral nutrition (TPN) in children is associated with sustained hyperinsulinemia due to a high nutriment infusion flow $12 \mathrm{~h} / 24 \mathrm{~h}$, with plausible lipotoxicity secondary to repeated lipid infusions and with changes in incretin hormone release. The aim of this study was to test whether long-term TPN can lead to an alteration in $\beta$-cell function. Thirteen children (age $9.5 \pm$ $3.9 \mathrm{y}$ ) on total TPN without obvious alternation in glucose tolerance were included. $\beta$-Cell function was quantified with an intravenous glucose tolerance test (IVGTT) and a graded glucose infusion. First phase insulin release (FPIR) was low in five patients. The same demonstrated a lower insulin release under graded glucose infusion, although plasma glucose reached values as high as $15 \mathrm{mM}$. These data emphasize that metabolic conditions induced by TPN can lead to lower insulin secretory response to glucose. Patients who remain dependent on TPN are at risk of developing glucose tolerance disorders. (Pediatr Res 62: 624-629, 2007)
\end{abstract}

$\mathrm{R}^{\mathrm{i} s}$ isk factors for type 2 diabetes have been well identified for years. Among them, lipotoxicity, chronic hyperinsulinemia, and alteration in the enteroinsular axis have been debated (1-3). Clinical situations, such long-term long-term parenteral nutrition (TPN), encompassing these metabolic conditions are not frequently studied. In theory, they could lead to alteration in glucose homeostasis or insulin release. In one pediatric cohort followed in two children's hospitals in Paris, the appearance of some cases of chronic and unremitting hyperglycemia during infusion, requiring insulin, suggested that TPN could promote glucose homeostasis disorders.

In examples like intestinal mucosa deficiency or neonatal extended intestinal resections, TPN has dramatically changed the prognosis $(4,5)$. Adequate nutrition is now provided to these children as daily home care. However, TPN is a nonphysiologic route of nutrient delivery. Nutrient mixtures are infused nightly over 10-14 h in sick children in whom caloric needs are equal or greater than in healthy children. High

Received March 7, 2007; accepted June 14, 2007.

Correspondence: Jacques Beltrand, M.D., Inserm U690, "Hôpital Robert Debré," 48 Boulevard Sérurier, 75019 Paris, France; e-mail: Jacques.beltrand@rdebre.inserm.fr

This work was partly supported by a grant from the Benjamin Delessert Institute and Inserm (Institut de la santé et de la recherché médicale). Jacques Beltrand was supported by a clinical research fellowship form Gallia Laboratory and from the "Association des Juniors en Pédiatrie" (France). glucose and insulin secretagogue nutrients induce chronic hyperinsulinemia lasting approximately $12 \mathrm{~h}$ per day (6). High lipid infusion rates could promote peripheral and central lipotoxicity. Moreover, some intestinal diseases have been shown to be associated with an alternation in incretin hormone release (7).

Insulin release in children on TPN was evaluated in one study 10 y ago (8). It was measured during an intravenous glucous tolerance test (IVGTT) and a hyperglycemic clamp. No obvious alterations in insulin release were observed. Patients had an insulin response to IVGTT similar to that of control children of the same age. Insulin release was greater than that in healthy young adults during a hyperglycemic clamp. However, patients were not observed among standardized metabolic conditions. Many of them were not totally dependent on TPN. Indeed, $\beta$-cell failure could not be reported there.

The aim of the study was to test whether metabolic conditions associated with long-term TPN could lead to an alteration $\beta$-cell function before any obvious alteration in glucose tolerance.

\section{METHODS}

Patients. Thirteen children on long-term TPN were included. Inclusion criteria were the following: children on PN since birth and for at least $5 \mathrm{y}$, $>80 \%$ of their daily caloric intake via the parenteral route, no obvious alternation in glucose tolerance as defined by fasting glycemia (before the beginning of TPN) $<6.93 \mathrm{mM}$ and $\mathrm{Hb} \mathrm{A}_{1 \mathrm{C}}$ level $<6 \%$ at the time of the study, and no drugs known to affect glucose tolerance.

Patients were hospitalized for $4 \mathrm{~d}$ in the Clinical Investigation Unit at the Robert Debré Hospital. TPN was infused between $1600 \mathrm{~h}$ and $0400 \mathrm{~h}$. Tests began $6 \mathrm{~h}$ after the end of infusion. Glucose and insulin were infused in the central venous catheter used for parenteral infusion (superior vena cava). Written informed consent from parents and assent from children were obtained. The study protocol was reviewed and approved by the ethical committee of Paris-St. Louis University.

Insulin sensitivity. Insulin sensitivity was measured with a 2-h euglycemic hyperinsulinemic clamp as described by de Fronzo and Beckles (9). First, a bolus of insulin was followed by a continuous infusion rate of $40 \mathrm{mU} / \mathrm{m}^{2} / \mathrm{min}$. Plasma glucose was clamped at $5.5 \mathrm{mM}$ with a variable rate of $30 \%$ glucose solution. Peripheral insulin sensitivity was determined from the amount of

Abbreviations: FFM, fat-free mass; FPIR, first phase insulin release; GDI, glucose disposal index; IVGTT, intravenous glucose tolerance test; TPN, long-term parenteral nutrition 
Table 1. Characteristics of the patients

\begin{tabular}{|c|c|c|c|c|c|c|}
\hline Patient & 1 & 2 & 3 & 4 & 5 & 6 \\
\hline Age, y & 10 & 6 & 6 & 6 & 18 & 16 \\
\hline Sex & M & M & F & F & $\mathrm{F}$ & M \\
\hline Tanner stage & I & I & I & I & IV & IV \\
\hline Weight, kg (SD) & $30(+0.5)$ & $20(0)$ & $21.0(+0.5)$ & $20.9(+1.0)$ & $50.0(0)$ & $58.4(-0.8)$ \\
\hline Height, cm (SD) & $131(-1)$ & $112(-0.5)$ & $115(+0.5)$ & $102(-2.5)$ & $163(+0.3)$ & $169(-0.7)$ \\
\hline BMI, $\mathrm{kg} / \mathrm{m}^{2}$ (SD) & $7.5(1.7)$ & $15.9(0.5)$ & $15.9(0.5)$ & $20.1(3.3)$ & $18.8(0.1)$ & $20.4(0.2)$ \\
\hline $\mathrm{FM}, \%$ & 26.7 & 18.1 & 19.6 & 38.9 & 29.1 & 18.5 \\
\hline $\begin{array}{l}1 \text { st }+2 \text { nd generation family } \\
\text { history }\end{array}$ & $\mathrm{N}$ & Y & $\mathrm{N}$ & $\mathrm{Y}$ & $\mathrm{N}$ & $\mathrm{Y}$ \\
\hline $\mathrm{Hb} \mathrm{A} \mathrm{A}_{1 \mathrm{C}}$ & 5.4 & 4.5 & 4.9 & 4.4 & 5 & 5.5 \\
\hline Fasting glycemia, mmol/L & 4.9 & 4.6 & 5.0 & 5.6 & 6.0 & 5.6 \\
\hline Fasting serum insulin, mUI/L & 2.9 & 2.1 & 2.9 & 4.1 & 4.9 & 16.5 \\
\hline Fasting $\mathrm{HGO}, \mathrm{mg} / \mathrm{kg} / \mathrm{min}$ & 2.8 & 4.9 & 2.6 & 3.8 & 6.9 & 3.1 \\
\hline Intestinal disease & $\begin{array}{l}\text { Neonatal } \\
\text { volvulus }\end{array}$ & $\begin{array}{l}\text { Hirschsprung } \\
\text { disease }\end{array}$ & $\begin{array}{l}\text { Chronic intestinal } \\
\text { pseudo obstruction } \\
\text { syndrome }\end{array}$ & Epithelial dysplasia & $\begin{array}{l}\text { Chronic intestinal } \\
\text { pseudo obstruction } \\
\text { syndrome }\end{array}$ & $\begin{array}{l}\text { Chronic intestinal } \\
\text { pseudo obstruction } \\
\text { syndrome }\end{array}$ \\
\hline Small intestine $(\mathrm{cm})$ & 41 & 80 & 27 & Intact & 180 & Intact \\
\hline
\end{tabular}

FM, fat mass; N, no; Y, yes.

glucose required to maintain euglycemia over the final $40 \mathrm{~min}$ at steady state reported for glycemia at the steady state.

Hepatic glucose output (HGO) was measured with $\left[{ }^{2} \mathrm{H}\right]$-glucose administered as a bolus $(5 \mathrm{mg} / \mathrm{kg})$ starting $240 \mathrm{~min}$ before starting insulin infusion followed by a constant infusion rate until the end of the test. Isotopic enrichment was determined 3, 4, and $6 \mathrm{~h}$ after the end of the parenteral infusion and at steady state. We could then check that glucose output was constant and at a fasting equivalent rate before the beginning of the clamp.

IVGTT. The acute insulin response was determined by IVGTT (10). After obtaining baseline samples, an IV bolus of glucose was injected $(0.5 \mathrm{~g} / \mathrm{kg}$ body weight). Blood samples for glucose and insulin were obtained at 1, 3, 5, and $10 \mathrm{~min}$ after the bolus. Glucose disposal index (GDI) was calculated as logarithm of product of insulin sensitivity and sum of 1 and 3 min of serum insulin.

Graded IV glucose infusion. Insulin secretion was measured using a graded IV glucose stimulation. Glucose was infused over 40-min periods at infusion rates of $4,8,12,16$, and $30 \mathrm{mg} / \mathrm{kg} / \mathrm{min}$, respectively. Blood samples were taken every $10 \mathrm{~min}$ to measure plasma glucose and at $30,40,70,80,110$, $120,150,160,190$, and 200 min to measure insulin and $\mathrm{C}$ peptide concentrations. The test was stopped if the plasma glucose concentration was $>22$ $\mathrm{mM}$.

GLP-1 release. GLP-1 (7-36 amide) release response to enteral stimulation was determined using an oral load of glucose $(50 \mathrm{~g})$. Blood samples were collected at baseline and at 30 and $120 \mathrm{~min}$. GLP-1 release is maximum at 30 $\mathrm{min}$ and returns to baseline values at $120 \mathrm{~min}$.

Analytical methods. Plasma glucose concentrations were measured by the glucose oxidase method (Glucose Analyzer GM9, Analox, London, UK). Free fatty acids were measured by an enzymatic colorimetric method (NEFA C, Wako Chemicals GmbH, Neuss, Germany). Serum insulin concentrations were measured using an immunoradiometric assay (Bi-Insulin IRMA, CIS Bio International, Gif sur Yvette, France). The cross-reactivity with proinsulin and des 31,32 split proinsulin was $<1 \%$. The detection limit was $0.5 \mathrm{mU} / \mathrm{L}$. The interassay coefficient of variation was $<8 \%$. Serum GLP-1 (7-36) amide concentrations were measured using an immunoradiometric assay (Linco Research, St. Charles, MO). Alanine transaminase (ALT), aspartate transaminase (AST), gamma-glutamyl transferase, and alkaline phosphatase levels were determined by enzymatic methods using an ADVIA analyzer (Bayer Diagnostics, Puteaux, France). Anti-glutamic acid decarboxylase (GAD) autoantibodies and anti-tyrosine phosphatase (IA-2) autoantibodies were determined by radioimmunossays (GAD-AB and IA2-AB, CIS Bio International). Body composition was assessed by dual energy $\mathrm{x}$-ray absorptiometry (GE Medical Systems, Prodigy Lunar Radiation, Madison, WI).

Statistical considerations. This was an exploratory study. Data were analyzed with SAS software version 8-02 (SAS, Cary, NC). Data are expressed as mean \pm SE. We compared groups using the nonparametric Wilcoxon rank test. A $p$ value $<0.05$ was considered statistically significant.

\section{RESULTS}

Subjects. Characteristics of the subjects are shown in Table 1. Thirteen children and adolescents (eight girls and five boys) were included. Median of age was $9.5 \mathrm{y}$ (range, 6.2-18.2). Children were either prepubertal or at the end of puberty. Median body mass index (BMI) was $+0.45 \mathrm{SD}$ (range, -0.29 to +3.28 ). One patient was obese (BMI, 3.28 SD). The mean percentage of fat mass was $25.8 \%$ (range, $18.5 \%-38.9 \%$ ). $\mathrm{Hb}$ $\mathrm{A}_{1 \mathrm{C}}$ was normal in all patients (median, 5\%) except one boy in whom it reached $6.0 \%$. Eight had second-generation family history of type 2 diabetes. One had first-generation family history.

Liver function was assessed on hepatic enzymes concentration. Both ALT and AST were increased in four patients (AST: 77, 110, 266, $96 \mathrm{UI} / \mathrm{L}$, respectively, in patients 3, 4, 11, 13; normal range, 5-45 UI/L; ALT: 47, 65, 241, $59 \mathrm{UI} / \mathrm{L}$, respectively, in patients $3,4,11,13$; normal range, 5-45 UI/L). AST was elevated in another patient (AST: $58 \mathrm{UI} / \mathrm{L}$ in patient 2). Alkaline phosphatase blood concentration was normal in all patients. Gamma-glutamyl transpeptidase (GGT) blood concentration was elevated in eight patients $(157,95$, $116,42,54,41,373,58 \mathrm{UI} / \mathrm{L}$, respectively, in patients $1,2,3$, 4, 5, 7, 11, 13; normal range, 7-25 UI/L).

To exclude an ongoing autoimmune process, autoantibodies associated with type 1 diabetes were measured. Anti-GAD and anti-IA2 were negative in all patients, except in one girl in whom anti-IA2 was positive (patient 12; IA2: 2.1).

Children were on TPN because of extended intestinal resection or mucosal dysfunction. TPN was infused nightly in all children over 10-14 h. Characteristics of TPN are summarized in Table 2. Mean glucose and lipid flows were 13.6 and 2.0 $\mathrm{mg} / \mathrm{kg} \cdot \mathrm{min}^{-1}$ (range, 8.0-18.5 and 0-3.3), respectively.

Insulin secretion. Results of IVGTT could separate two groups of patients: patients with a high first phase insulin release (FPIR) and patients with a lower one. Despite a similar increase in plasma glucose, five patients demonstrated a lower FPIR evaluated by the sum of insulin release at 1 and $3 \mathrm{~min}$. It was below or around the first tertile of $1+3 \mathrm{~min}$ (first tertile $=68.1 \mathrm{mIU} / \mathrm{L}$, second tertile $=151.6 \mathrm{mIU} / \mathrm{L}$ ). Mean $1+3$ min insulin sum was $55.3 \pm 6.09$ in these patients in contrast to $189 \pm 22.5 \mathrm{mIU} / \mathrm{L}$ in the remaining patients $(p=$ 0.002) (Fig. 1). It suggests us that if insulin secretion reached 
Table 1. Continued

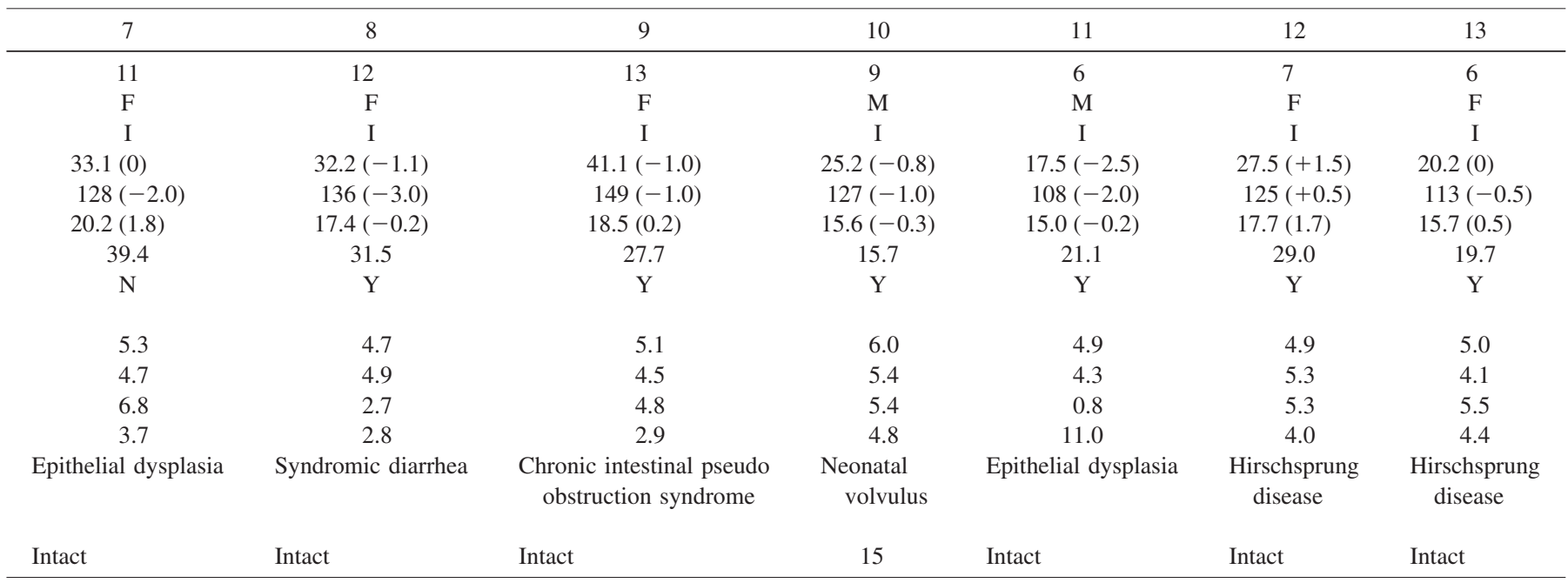

physiologic values in these patients, they could have a lower insulin secretory response to glucose. A graded IV glucose infusion was then performed to assess this lower $\beta$-cell sensitivity to glucose stimulation.

Graded glucose infusion showed two different patterns of insulin release similar to ones found by IVGTT. The mean maximum glucose concentration achieved was similar in chil- dren with low FPIR and in those with higher FPIR (15.14 \pm $0.65 \mathrm{mM}$ versus $16.01 \pm 0.11 \mathrm{mM}, p=0.59$ ). By contrast, insulin secretion was almost 2.6-fold lower in patients with low FPIR. Insulin release only reached a mean value of 67.8 $\mathrm{mIU} / \mathrm{L} \pm 23.8$ in patients with an alteration in FPIR, although it reached a mean value of $176.4 \pm 38.1 \mathrm{mIU} / \mathrm{L}$ in patients without any alteration $(p=0.028)$ (Fig. 2$)$. These

Table 2. Characteristics of TPN

\begin{tabular}{|c|c|c|c|c|c|c|c|c|c|c|c|c|c|}
\hline Patient & 1 & 2 & 3 & 4 & 5 & 6 & 7 & 8 & 9 & 10 & 11 & 12 & 13 \\
\hline Parenteral nutrition duration (y) & 10 & 6 & 6 & 6 & 18 & 16 & 11 & 12 & 13 & 9 & 6 & 7 & 6 \\
\hline Infusion duration per day (h) & 12 & 12 & 12 & 12 & 12 & 14 & 12 & 14 & 10 & 12 & 13 & 12 & 12 \\
\hline Glucose intake $(\mathrm{g} / \mathrm{kg} / \mathrm{d})$ & 6.6 & 7.3 & 14.6 & 13.0 & 6.0 & 7.9 & 10.5 & 7.2 & 9.8 & 9.1 & 12.5 & 9.8 & 13.5 \\
\hline Lipids intake (g/kg/d) & 1.5 & 2.5 & 1.9 & 1.9 & 0 & 1.7 & 0.8 & 0.9 & 1.7 & 1.8 & 2.3 & 1.4 & 1.5 \\
\hline Amino acid intake $(\mathrm{g} / \mathrm{kg} / \mathrm{d})$ & 1.5 & 4.5 & 2.0 & 1.8 & 1.1 & 2.1 & 1.8 & 2.1 & 1.9 & 1.6 & 2.3 & 1.6 & 1.4 \\
\hline Caloric intake $(\mathrm{kcal} / \mathrm{kg} / \mathrm{d})$ & 39.8 & 51.9 & 75.9 & 69.3 & 21.9 & 43.7 & 42.3 & 28.5 & 38.9 & 52.4 & 50.3 & 39.3 & 53.4 \\
\hline Glucose infusion rate $(\mathrm{mg} / \mathrm{kg} / \mathrm{min})$ & 9.1 & 10.3 & 20.3 & 18 & 7.6 & 10.9 & 14.6 & 8.5 & 16.2 & 12.6 & 16.1 & 13.6 & 18.5 \\
\hline Lipid infusion rate $(\mathrm{mg} / \mathrm{kg} / \mathrm{min})$ & 2 & 3.3 & 3.3 & 2.5 & 0 & 2.3 & 1.0 & 1.0 & 2.8 & 2.7 & 3.19 & 2.0 & 2.05 \\
\hline
\end{tabular}

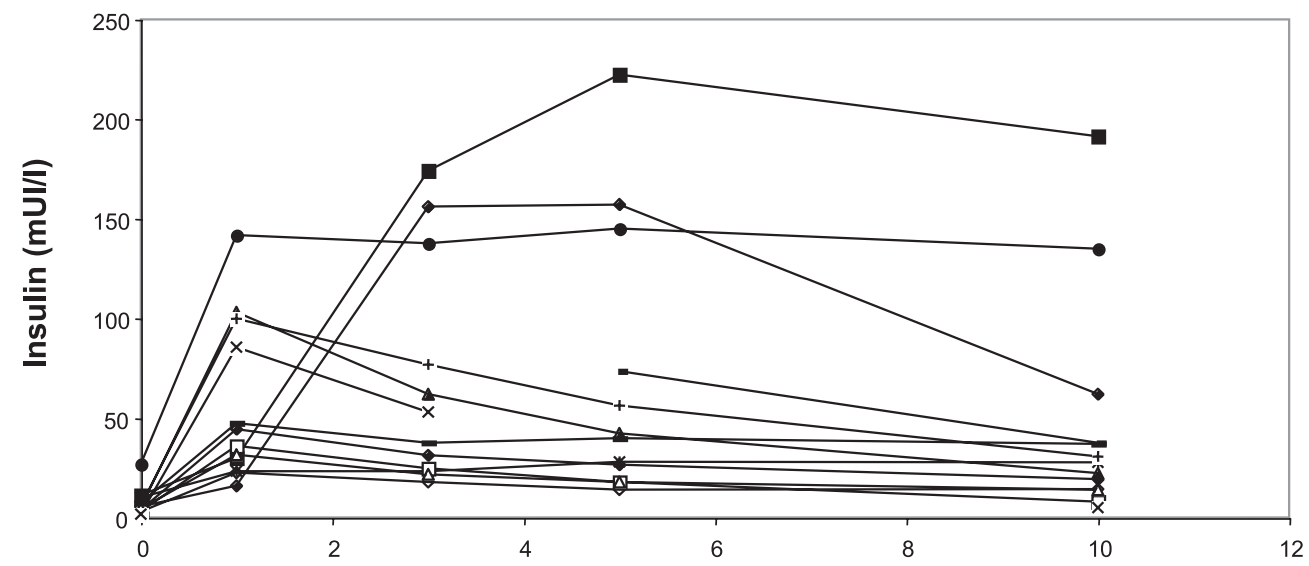

Time (mn)

\begin{tabular}{|c|c|c|c|c|c|c|c|c|c|c|c|c|c|}
\hline Patient & $\begin{array}{r}1 \\
\bullet\end{array}$ & $\begin{array}{l}2 \\
-\end{array}$ & $\begin{array}{r}3 \\
\Delta\end{array}$ & $\begin{array}{l}4 \\
0\end{array}$ & $\begin{array}{l}5 \\
* \\
\end{array}$ & 6 & $\begin{array}{r}7 \\
+ \\
\end{array}$ & $\begin{array}{r}8 \\
\square\end{array}$ & $\begin{array}{l}9 \\
-\end{array}$ & 10 & $\begin{array}{l}11 \\
\square\end{array}$ & $\begin{array}{l}12 \\
\Delta\end{array}$ & $\begin{array}{r}13 \\
\times \\
\end{array}$ \\
\hline $\begin{array}{c}1+3 \\
(\mathrm{mU} / \mathrm{l})\end{array}$ & 172 & NM & 165 & 40.4 & 46.6 & 279.4 & 176.6 & 204 & 85 & 75.6 & 60.6 & 53.1 & 138.2 \\
\hline
\end{tabular}

Figure 1. IVGTT: FPIR (mIU/L) release. Sum of insulinemia at 1 and $3 \mathrm{~min}$ is summarized in the table. 


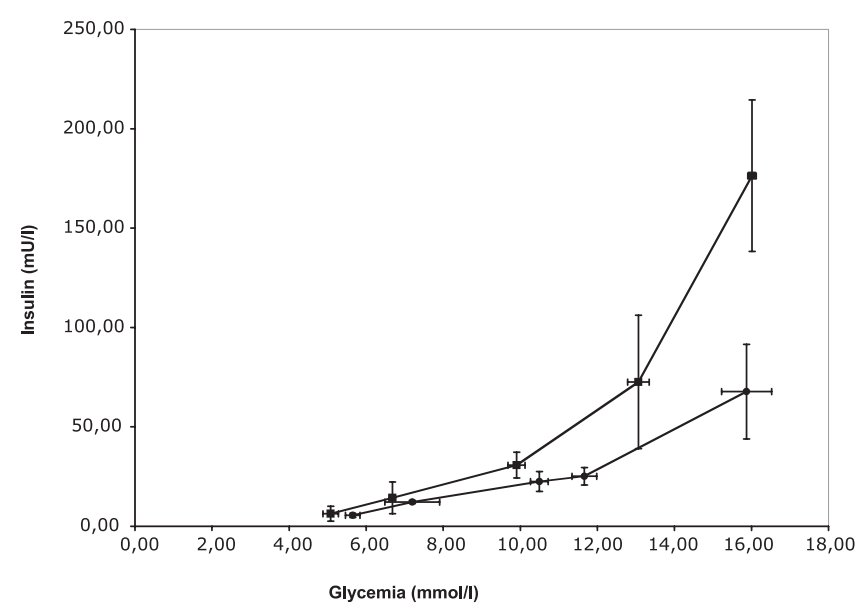

Figure 2. Insulin (mU/L) release during graded IV glucose infusion in patients with normal FPIR and patients with low FPIR. $\mathbf{\square}: 1+3>80 \mathrm{mUI} / \mathrm{L}$; ๑: $1+3<80 \mathrm{mUI} / \mathrm{L}$.

patients demonstrated then a lower insulin secretory response to glucose.

Insulin sensitivity. Peripheral glucose uptake (mean) adjusted for fat-free mass (FFM) was measured during euglycemic hyperinsulinemic clamp. Most of the patients had normal or high insulin sensitivity using previously reported values in healthy children (11). Mean peripheral glucose uptake was 10.7

$\mathrm{mg} /$ $\mathrm{min} \cdot \mathrm{kg} \mathrm{FFM}{ }^{-1} \pm 1.6 \mathrm{mg} / \mathrm{min} \cdot \mathrm{kg} \mathrm{FFM}{ }^{-1}$ in girls and $12.1 \pm$ 3.2 in boys. There was no difference between patients irrespective of whether they had low or high insulin secretion during IVGTT or graded IV glucose infusion (12.7 \pm 1.5 versus $11.8 \pm 2.3, p=0.95)$. Decreased insulin sensitivity was found only in one boy (mean $=4.7 \mathrm{mg} / \mathrm{min} \cdot \mathrm{kg} \mathrm{FFM}^{-1}$ ).

All patients had normal or increased fasting hepatic glucose output after $6 \mathrm{~h}$ of cessation of infusion $4.4 \pm 2.3 \mathrm{mg} / \mathrm{kg} / \mathrm{min}$. It was not statistically different between children with or without low FPIR $(6.07 \pm 1.2 \mathrm{mg} / \mathrm{kg} / \mathrm{min}$ versus $3.4 \pm 0.3$ $\mathrm{mg} / \mathrm{min} / \mathrm{kg}, p=0.28)$. HGO was abolished at clamp steady state in all patients. Hepatic insulin sensitivity was normal.

GLP-1 release. To assess whether there was stimulation of the enteroinsular axis even in children with poor oral intake, the active form of circulating GLP-1 was measured after an oral glucose load. In healthy adult subjects, a test meal is followed by a threefold increase in GLP-1 (12).

This test was performed in nine patients. The remaining patients had a complete intolerance of oral feeding. There were no increases in GLP-1 in any patients after the oral load (Fig. 3), indicating that the enteroinsular axis was not at all stimulated.

Relationship between FPIR and insulin sensitivity. To correlate FPIR, insulin sensitivity, and $\beta$-cell function, we calculated the GDI. GDI is the product of insulin sensitivity and FPIR. It has been shown to be constant in subjects with no $\beta$-cell failure (13). A decrease in insulin sensitivity is then physiologically compensated by a higher insulin release in healthy subjects, whereas subjects with higher insulin sensitivity demonstrate a lower FPIR. There is a hyperbolic relationship between FPIR and insulin sensitivity. By contrast,

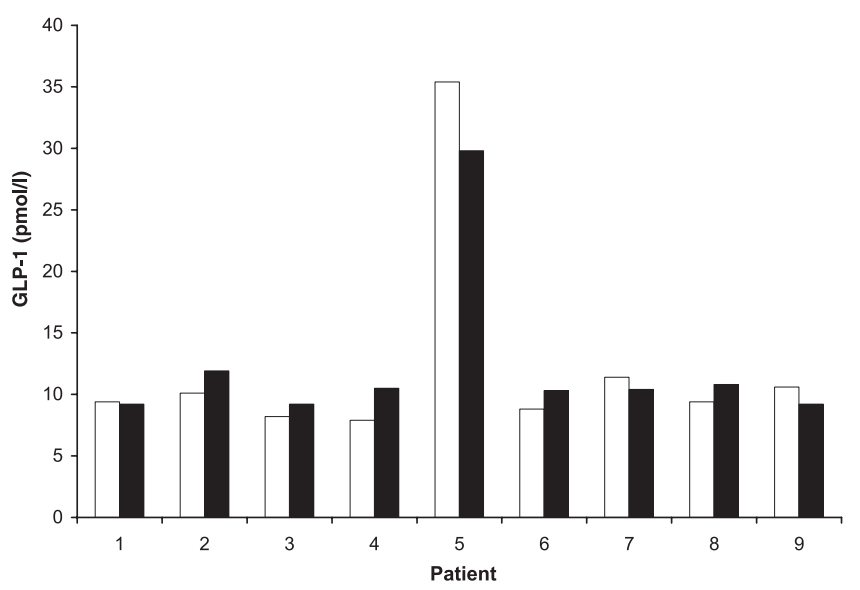

Figure 3. Fasting (open columns) and oral stimulated (60 min post-glucose oral load; solid columns) GLP-1 (pmol/L) active form release.

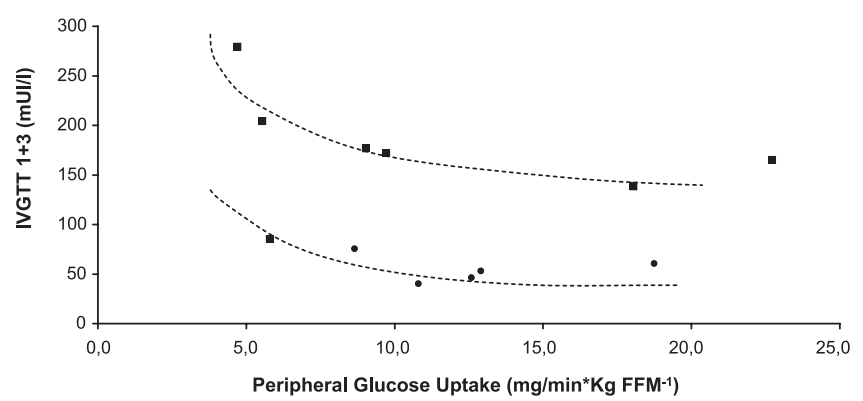

Figure 4. GDI. Relationship between insulin sensitivity (mean adjusted for FFM and glycemia) and FPIR (insulinemia $1+3$ during IVTT). $\mathbf{0}$ : patients with normal FPIR; $\bullet$ : patients with low FPIR.

subjects with nonappropriated $\beta$-cell function (prediabetic or diabetic patients) have a loss of insulin release compensation. GDI is then lower, and subjects are plotted on lower hyperbolic graphs.

Indeed, in this study, patients with lower FPIR have lower GDI than patients with higher FPIR (GDI: $3.6 \pm 0.06$ versus $3.9 \pm 0.1 ; p=0.03)$. Patients with lower FPIR were plotted on lower graphs, although the other patients were plotted on higher hyperbolic graphs (Fig. 4).

\section{DISCUSSION}

Among 300 children on long-term TPN followed in two pediatric gastroenterology units, three children developed chronic hyperglycemia without any other risks factors than TPN. This incidence of glucose metabolism disorder, higher than in the general population, suggests that TPN could alter insulin secretion. The aim of the present study was to assess whether a lower insulin secretory response to glucose could be detected in children on TPN. Five children demonstrated a low first phase of insulin. A reduced first phase has been shown to be a risk factor for progression to type 2 diabetes even though the rate of insulin release is still in physiologic values and if glycemia during infusion is still normal. It is the earliest detectable defect of $\beta$-cell function (14). In first-degree relatives of patients with type 1 diabetes, a low FPIR associated with antibodies against pancreatic antigens has been demonstrated to be predictive of progression to diabetes (15). 
Insulin release was further investigated with a graded IV glucose infusion that has been shown to be a very sensitive test to measure insulin release in response to glucose in subjects with no alternation in insulin release. It has been used, for example, in healthy subjects with heterozygous mutation of glucokinase or in subjects exposed to diabetes in utero to demonstrate whether lower insulin secretion can be assessed (16-18). This test has a high sensitivity to measure $\beta$-cell response to glucose stimulus. Children with lower FPIR demonstrated lower insulin release under sustained and graded glucose infusion despite high levels of blood glucose (15.3 $\mathrm{mM})$. Insulinemia in children with low FPIR were 2.6-fold lower than values in patients without alteration in FPIR. Graded glucose infusion could attest to a lower insulin secretory response to glucose in these patients, as previously described in others groups of healthy patients with different risk factors $(16,17)$. Patients with low FPIR demonstrated simultaneously a lower GDI. When FPIR were plotted with insulin sensitivity, patients with mild or high insulin release fitted the same hyperbolic graphs. Taken together, these data point to an altered secretory response to glucose in some patients even if insulin release still reaches physiologic values. This group of patients could be at risk of developing $\beta$-cell failure and glucose tolerance abnormalities.

Insulin sensitivity was normal in all our patients except one patient who demonstrated decreased insulin sensitivity compensated by a high insulin release. This patient was the only one studied during puberty (Tanner stage 4).

At least three risk factors of glucose homeostasis disorders can be found in these children. Here we can eliminate an autoimmune process, as children with lower insulin secretory response to glucose had no autoantibodies against pancreatic antigens.

TPN exposes children to high glucose and nutrient flow rates $12 \mathrm{~h} / \mathrm{d}$ from birth onward. High insulin concentrations surrounding $\beta$ cells could inhibit glucose-mediated insulin secretion pathways via overstimulation of its own receptor on the $\beta$-cell membrane $(19,20)$. Indeed, it is difficult to assess the direct effect of hyperinsulinemia in such patients, although it seems to be an important risk factor.

Peripheral insulin resistance induced by lipotoxicity associated with lipid infusion does not seem to be involved. It is been demonstrated that in healthy patients, lipid infusion induces a decrease in insulin sensitivity (21). Here insulin sensitivity was altered only in one patient. In other patients, insulin sensitivity was in the normal range or even increased with regard to values previously reported in healthy children (11). Insulin sensitivity was similar in patients with low or normal FPIR (mean, 12.7 versus 11.7).

Moreover, these patients do not show alteration in hepatic insulin sensitivity under insulin infusion. TPN has been reported to be frequently associated with mild to severe steatosis induced by glucose and lipid infusions, even with normal blood liver tests (22). It appears early after the beginning of TPN and may contribute, along with other risks factors, to fibrosis and later cirrhosis (23). It is thought that steatosis may induce modifications of insulin sensitivity similar to these reported in nonalcoholic steatosis associated with obesity (24).
Indeed, it has been demonstrated to be an inflammatory state that disturbs insulin effects on hepatic glucose output via such cytokines like interleukin-6 (25). In patients in this study, hepatic glucose output was suppressed by insulin infusion.

Alteration in $\beta$-cell function induced by lipid infusion may be expected. Free fatty acid accumulation in $\beta$-cell could inhibit insulin secretion pathway. It could inhibit $\mathrm{K}^{+}$dependent channels via the mitochondrial expression of decoupling proteins like UCP-2 (26). It increases malonylcoenzyme A and induces ceramide production that could enhance cellular apoptosis (3).

Low GLP-1 release could be involved in the disorders reported here. Even in patients with poor oral intake, GLP-1 secretion is not stimulated. This has been observed irrespective of the nature of the original disease, the nutritional pattern or the length of the residual small bowel. Alteration in GLP-1 release has been previously reported in adult patients with an intestinal resection (7). We can hypothesize that GLP-1 secretion has not been stimulated from birth in these children because of intestinal resection, mucosal dysfunction, or lack of oral intake. The role of this incretin in enhancing insulin release and hepatic glucose uptake has been well documented $(27,28)$. GLP-1 has also been implicated in the postnatal maturation and trophicity of $\beta$ cells, at least in rodent models (29-31). GLP-1 infusion together with TPN could improve insulin secretion in children on TPN with lower insulin secretory response to glucose.

Because of the small size of the study population, it is difficult to identify clinical factors associated with the lower insulin secretory response to glucose. Interestingly, a family history of type 2 diabetes was frequently observed in patients with a low FPIR. Three of five patients with alteration in insulin release had a second-degree family history and one a first-degree history. We found no evidence of correlation between insulin release and TPN composition or duration. Most of our subjects had a fat mass percentage superior to normal range with regard to values previously reported in healthy children (32). Three of five patients had a percentage $>29 \%$.

In conclusion, we report that metabolic conditions associated with long-term TPN can induce a decrease in insulin secretory response to glucose, which was evidenced before any obvious alteration in glucose tolerance in these children. These patients are at high risk of developing an alteration in glucose metabolism and must be closely followed, especially when they are candidates for intestinal transplantation.

\section{REFERENCES}

1. Toft-Nielsen MB, Damholt MB, Madsbad S, Hilsted LM, Hughes TE, Michelsen BK, Holst JJ 2001 Determinants of the impaired secretion of glucagon-like peptide-1 in type 2 diabetic patients. J Clin Endocrinol Metab 86:3717-3723

2. Weir GC, Bonner-Weir S 2004 Five stages of evolving beta-cell dysfunction during progression to diabetes. Diabetes 53:S16-S21

3. Unger RH 2003 The physiology of cellular liporegulation. Annu Rev Physiol 65:333-347

4. Vargas JH, Ament ME, Berquist WE 1987 Long-term home parenteral nutrition in pediatrics: ten years of experience in 102 patients. J Pediatr Gastroenterol Nutr 6:24-32

5. Colomb V 1998 Home artificial nutritional support in gastrointestinal disease. Curr Opin Clin Nutr Metab Care 1:395-399 
6. Byrne WJ, Lippe BM, Strobel CT, Levin SR, Ament ME, Kaplan SA 1981 Adaptation to increasing loads of total parenteral nutrition: metabolic, endocrine, and insulin receptor responses. Gastroenterology 80:947-956

7. Lauritsen KB, Christensen KC, Stokholm KH 1980 Gastric inhibitory polypeptide (GIP) release and incretin effect after oral glucose in obesity and after jejunoileal bypass. Scand J Gastroenterol 15:489-495

8. Lienhardt A, Rakotoambinina B, Colomb V, Souissi S, Sadoun E, Goulet O, Robert JJ, Ricour C 1998 Insulin secretion and sensitivity in children on cyclic total parenteral nutrition. JPEN J Parenter Enteral Nutr 22:382-386

9. DeFronzo RA, Beckles AD 1979 Glucose intolerance following chronic metabolic acidosis in man. Am J Physiol 236:E328-E334

10. Bingley PJ, Colman P, Eisenbarth GS, Jackson RA, McCulloch DK, Riley WJ, Gale EA 1992 Standardization of IVGTT to predict IDDM. Diabetes Care 15:1313-1316

11. Moran A, Jacobs DR Jr, Steinberger J, Hong CP, Prineas R, Luepker R, Sinaiko AR 1999 Insulin resistance during puberty: results from clamp studies in 357 children. Diabetes 48:2039-2044

12. Rask E, Olsson T, Soderberg S, Johnson O, Seckl J, Holst JJ, Ahren B 2001 Impaired incretin response after a mixed meal is associated with insulin resistance in nondiabetic men. Diabetes Care 24:1640-1645

13. Kahn SE, Prigeon RL, McCulloch DK, Boyko EJ, Bergman RN, Schwartz MW, Neifing JL, Ward WK, Beard JC, Palmer JP, Porte D Jr 1993 Quantification of the relationship between insulin sensitivity and beta-cell function in human subjects. Evidence for a hyperbolic function. Diabetes 42:1663-1672

14. Bunt JC, Krakoff J, Ortega E, Knowler WC, Bogardus C 2007 Acute insulin response is an independent predictor of type 2 diabetes mellitus in individuals with both normal fasting and 2-h plasma glucose concentrations. Diabetes Metab Res Rev 23:304-310

15. Robert JJ, Deschamps I, Chevenne D, Roger M, Mogenet A, Boitard C 1991 Relationship between first-phase insulin secretion and age, HLA, islet cell antibody status, and development of type I diabetes in 220 juvenile first-degree relatives of diabetic patients. Diabetes Care 14:718-723

16. Byrne MM, Sturis J, Fajans SS, Ortiz FJ, Stoltz A, Stoffel M, Smith MJ, Bell GI, Halter JB, Polonsky KS 1995 Altered insulin secretory responses to glucose in subjects with a mutation in the MODY1 gene on chromosome 20. Diabetes 44:699-704

17. Byrne MM, Sturis J, Menzel S, Yamagata K, Fajans SS, Dronsfield MJ, Bain SC, Hattersley AT, Velho G, Froguel P, Bell GI, Polonsky KS 1996 Altered insulin secretory responses to glucose in diabetic and nondiabetic subjects with mutations in the diabetes susceptibility gene MODY3 on chromosome 12. Diabetes 45:15031510

18. Sobngwi E, Boudou P, Mauvais-Jarvis F, Leblanc H, Velho G, Vexiau P, Porcher R, Hadjadj S, Pratley R, Tataranni PA, Calvo F, Gautier JF 2003 Effect of a diabetic environment in utero on predisposition to type 2 diabetes. Lancet 361:1861-1865

19. Elahi D, Nagulesparan M, Hershcopf RJ, Muller DC, Tobin JD, Blix PM, Rubenstein AH, Unger RH, Andres R 1982 Feedback inhibition of insulin secretion by insulin: relation to the hyperinsulinemia of obesity. N Engl J Med 306:1196-1202

20. Ohsugi M, Cras-Meneur C, Zhou Y, Bernal-Mizrachi E, Johnson JD, Luciani DS Polonsky KS, Permutt MA 2005 Reduced expression of the insulin receptor in mouse insulinoma (MIN6) cell reveals multiple roles of insulin signaling in gene expression, proliferation, insulin content, and secretion. J Biol Chem 280:4992-5003

21. Magnan C, Cruciani C, Clement L, Adnot P, Vincent M, Kergoat M, Girard A, Elghozi JL, Velho G, Beressi N, Bresson JL, Ktorza A 2001 Glucose-induced insulin hypersecretion in lipid-infused healthy subjects is associated with a decrease in plasma norepinephrine concentration and urinary excretion. J Clin Endocrinol Metab 86:4901-4907

22. Kelly DA 2006 Intestinal failure-associated liver disease: what do we know today? Gastroenterology 130:S70-S77

23. Kumpf VJ 2006 Parenteral nutrition-associated liver disease in adult and pediatric patients. Nutr Clin Pract 21:279-290

24. Cortez-Pinto H, Camilo ME, Baptista A, De Oliveira, AG De Moura MC 1999 Non-alcoholic fatty liver: another feature of the metabolic syndrome? Clin Nutr $18: 353-358$

25. Abiru S, Migita K, Maeda Y, Daikoku M, Ito M, Ohata K, Nagaoka S, Matsumoto T, Takii Y, Kusumoto K, Nakamura M, Komori A, Yano K, Yatsuhashi H, Eguchi K, Ishibashi H 2006 Serum cytokine and soluble cytokine receptor levels in patients with non-alcoholic steatohepatitis. Liver Int 26:39-45

26. Chan CB, De Leo D, Joseph JW, McQuaid TS, Ha XF, Xu F, Tsushima RG, Pennefather PS, Salapatek AM, Wheeler MB 2001 Increased uncoupling protein-2 levels in beta-cell are associated with impaired glucose-stimulated insulin secretion: mechanism of action. Diabetes 50:1302-1310

27. Thorens B, Waeber G 1993 Glucagon-like peptide-I and the control of insulin secretion in the normal state and in NIDDM. Diabetes 42:1219-1225

28. Colomb V, Leturque A, Guihot G, Loizeau M, Lavie S, Colomer S, Ricour C, Girard J 1995 Route of nutrient delivery affects insulin sensitivity and liver glucose transporter expression in rat. Am J Physiol 269:E827-E833

29. Abraham EJ, Leech CA, Lin JC, Zulewski H, Habener JF 2002 Insulinotropic hormone glucagon-like peptide-1 differentiation of human pancreatic islet-derived progenitor cell into insulin-producing cell. Endocrinology 143:3152-3161

30. Hardikar AA, Wang XY, Williams LJ, Kwok J, Wong R, Yao M, Tuch BE 2002 Functional maturation of fetal porcine beta-cell by glucagon-like peptide 1 and cholecystokinin. Endocrinology 143:3505-3514

31. Li Y, Hansotia T, Yusta B, Ris F, Halban PA, Drucker DJ 2003 Glucagon-like peptide-1 receptor signaling modulates beta cell apoptosis. J Biol Chem 278:471-478

32. van der Sluis IM, de Ridder MA, Boot AM, Krenning EP, de Muinck KeizerSchrama SM 2002 Reference data for bone density and body composition measured with dual energy x ray absorptiometry in white children and young adults. Arch Dis Child 87:341-347 